$\begin{array}{ll}\text { Balkanologie } & \begin{array}{l}\text { Balkanologie } \\ \text { Revue d'études pluridisciplinaires }\end{array} \\ & \text { Vol. } \mathbf{1 5} \mathrm{n}^{\circ} \mathbf{1} \mid \mathbf{2 0 2 0} \\ & \text { Mémoires performatives : faire des passés et des } \\ \text { présents }\end{array}$

\title{
Chasing the Past on the Margins of Greece
}

Pierre Sintès, Chasing the Past: Geopolitics of Memory on the Margins of Modern Greece, Liverpool, Provence University Press and Liverpool University Press, 2019.

\section{Russell King}

\section{(2) OpenEdition}

12 Journals

Electronic version

URL: https://journals.openedition.org/balkanologie/2554

DOI: $10.4000 /$ balkanologie. 2554

ISSN: 1965-0582

Publisher

Association française d'études sur les Balkans (Afebalk)

\section{Electronic reference}

Russell King, "Chasing the Past on the Margins of Greece", Balkanologie [Online], Vol. 15 n $^{\circ} 1$ | 2020, Online since 01 June 2020, connection on 05 August 2021. URL: http://journals.openedition.org/ balkanologie/2554 ; DOI: https://doi.org/10.4000/balkanologie.2554

This text was automatically generated on 5 August 2021.

(c) Tous droits réservés 


\section{Chasing the Past on the Margins of Greece}

Pierre Sintès, Chasing the Past: Geopolitics of Memory on the Margins of Modern Greece, Liverpool, Provence University Press and Liverpool University Press, 2019.

\section{Russell King}

\section{REFERENCES}

Sintès, Pierre, 2019, Chasing the Past: Geopolitics of Memory on the Margins of Modern Greece, Liverpool, Provence University Press and Liverpool University Press, 236 pages, ISBN 978-1-78694-089-6

1 This is a tour de force of historical geography and contemporary ethnography of migrant communities in Greece. Translated from French by Jenny Money, the author graciously acknowledges the translator's skill and patience in making the English version "a clearer and more understandable text than the original" (p.9) - the gold-standard achievement of a brilliant translator.

2 Pierre Sintès states that his key reference-point for the book is the Greek financial meltdown of 2008. The economic crisis affected Greece more severely than any other country, threatening not only the economic and social wellbeing of large shares of its population but also the country's continuing participation in the ongoing project of European integration (notably its membership of the eurozone) and hence its European identity. Viewed from mid-2020, the 2008 financial crisis now feels somewhat passé, superseded by two more crises that have dramatically affected Greece, Europe and the wider world. The first of these was the refugee crisis of 2015-2016 which particularly impacted the Greek islands bordering Turkey and the land borders with Bulgaria and North Macedonia, and the second is the ongoing coronavirus pandemic which struck Europe in 2020. Whilst a book published in 2019 could not have foreseen the pandemic, it is surprising to see almost no reference to the Syrian refugee crisis and the effects it 
has had on Greece. Both the islands facing the Turkish coast and the overland migration routes threading northwards through the Western Balkans can be considered important strategic flanks on the margins of modern Greece. In fact, the book seems to "stop" around 2012, a view confirmed by the dates in the bibliography. Nevertheless, the effect of any particular "crisis" as such is a minor theme in the overall work.

3 In a comprehensive introductory essay, the author sets out the conceptual and geographical frames for the rest of the book. Using the triadic framework of memory, identity and space, Sintès proposes that his main concern is the change in everyday lives of Greece's "new poor" in light of the economic crisis and its interactions with globalisation on the one hand and hierarchies of belonging to Greece on the other. The experience of two contrasting groups is selected for detailed analysis in subsequent chapters - that of the arrival and settlement throughout Greek territory of Albanian migrants since the early 1990s, and the revitalisation in exile of the historic Jewish community from the island of Rhodes. Through reference to these and other groups marginalised by the crisis and by the twists of history and geopolitics, Sintès aims to tease out the tensions between what he calls the "penetration of the global Zeitgeist of liberal post-modernity" (p.8) and the emergence of more radical discourses rooted in individualisation and embodied local identities.

Chapter 1, "Understanding Greece in the Modern World," is mainly descriptive, laying the foundations for the geopolitical positionality of Greece and its internal and external tensions, especially in relation to its Balkan hinterland. For Sintès, this positionality has been dominated in recent years by the break-up of Yugoslavia and Greece's alwaysdifficult relationship with Albania. This is because large numbers of migrants entered Greece from these regions after 1990, rapidly accounting for up to 1 million persons ( $10 \%$ of the Greek resident population compared to less than $2 \%$ in 1991). In the latter part of the chapter and set within a reasoned critique of the mostly Anglophone literature on the Albanian and Balkan migrations, Sintès describes his own field research within and around the margins of Greece. For him, as for many cultural geographers and anthropologists, locality is the key scale from which to observe the complexity of reality through the lens of the "exceptional normal" - an idea that I would have liked to have seen explained in more detail.

Chapter 2 is the first empirical chapter, and in it the author presents his research on the Albanian migration to Greece, one of the largest bilateral, cross-frontier movements in recent European history. Within a decade, a "stock" of 440,000 Albanians had settled in Greece. Rich in maps, statistics and ethnographic vignettes, the first half of the chapter gives a vivid account of this mass migration. One of the interesting aspects of the Albano-Greek migration is the way it has spread into all parts of the country, from the major cities of Athens and Thessaloniki to small towns, remote villages and the islands. This indicates a profound structural impact on several sectors of the Greek economy - industry, construction, intensive agriculture, pastoralism, tourism and carework - but in all cases, the Albanian migrants are performing lowwage and insecure jobs in the informal segment of a dual labour market. The demographic impacts of this migration are likewise important and variable: Albanians have accelerated the sprawling growth of the major cities, yet also staunched depopulation in highland villages. 
Sintès uses the interesting concept of relational space to explain the movements between Albania and Greece. I would add the parallel notion of relational time to interpret the shifting temporalities of movement, which range from short and initially exploratory work trips, to more regular and rhythmic seasonal migrations dictated by the labour regimes of agriculture and tourism, to family formation and long-term settlement. Another key aspect of relational time is the "before and after" of the 2008 crisis. For many migrant families, the crisis brutally upset their hitherto successful project of settling and integrating into Greece, forcing them either to return to Albania or to engage in various adaptive transnational practices to survive. Sintès finished his field research on Albanian migration to Greece in 2011, with the result that this latest phase of the story, which developed some years after the crisis hardened, is only hinted at.

7 In the final part of this long chapter, the author switches the temporal focus to enable him, through the participants' testimonies, to interpret the apparently "new" migratory mobilities through memories of the pre-communist past, when cross-border movements were common. Even during the communist era, clandestine bordercrossing was not unknown in this region, especially amongst the Greek-speaking and Orthodox minorities of southern Albania, including the pastoral Vlachs or Aromanians. These earlier cross-border ethnic family networks also extended to groups on the Greek side which were Albanian-speaking and, in some communities, Muslims, called Arvanites, Chams etc. However, cases of inter-community violence were also quite common, testified by various present-day memorials; these resurfaced after the border was opened in the 1990s, creating new "spaces of memory" (p.70).

Chapter 3 presents Sintès' second field study, this one on the now-dispersed Jewish community of Rhodes, seen as a "revitalised fragment of the Greek mosaic," in the words of the chapter's title. In this case, the story is less about contemporary migration and more about the memory-based mobilities of descendants of a community longdisplaced from an enclave within the old walled city. What these descendants engage in nowadays, from their globally dispersed diasporic locations, can be interpreted as a kind of "roots tourism" to view fragments of their heritage and past identity.

Following a detailed history of the multi-layered formation and exile of the Rhodian Jews, or "Rodesli," Sintès teases out the multiple tensions involved in preserving both the physical structure and memory of the Rhodes Juderia, including the restoration of its long-dilapidated Shalom synagogue into a major place of worship for visitors, tourist attraction and monument within the UNESCO world heritage site of the old town. The tourists are partly the descendants of the original community, including those who survived the Holocaust, and partly visiting Israelis, for whom Rhodes is an accessible tourist destination by boat or short-hop plane. Although some private houses have been reclaimed and restored (and a few even lived in) by the descendants of the original owners, the district has become dilapidated and socially downgraded, with abandoned and unsafe properties, squatters and refugees. The author clearly "feels" for the Juderia of Rhodes, and this leads him occasionally to overdo the anecdotes and value-judgements in this otherwise fascinating piece of historical ethnography.

In Chapter 4, another set of ethnographies is presented representing other localities across the northern Greek mountain borderlands - Filiates and Sagiada in Threspotia, Nymfaio in Greek Western Macedonia, and Krushevo across the border in North 
Macedonia. Each location represents new social, economic, demographic and ethnic dynamics in rural settings, even if the question is never addressed as to how "unique" (or "typical") each place is in terms of the processes observed. For Filiates, the return visits made by former residents now living in Athens and abroad bring the village alive for certain periods of the year - Christmas, Easter and, especially, the summer months. For many of those who live away from the village, rebuilding its social and cultural landscape is important, thereby creating a rural renaissance in this part of Greece as houses are restored and community customs are maintained. "Outsiders" also settle Albanian migrants, and property-buyers from Athens seeking a quiet life. At Sagiada, the tradition of polyphonic song and the patronal festival draw interest from far and wide, including from the ethnographer. Much further east, the remote village of Nymfaio, situated at 1300 metres and close to the Macedonian border, has become a desirable mountain repose, with smartly restored homes and an increasingly upmarket clientele. Sintès likens it to a rural gated community, with cars parked outside the entrance to the pedestrianised village. Here the aim is to promote a new kind of rural economy founded on sustainable tourism and new residents, based on Nymfaio's place in the official "network of traditional Greek communities." This policy is supported by EU-financed cultural restoration schemes, including cross-border twinning with the small town of Krushevo in North Macedonia where similar ambitions are being pursued, alongside "friendship and cooperation" associations based on common Vlach heritage.

Chapter 5 is the author's attempt, for the most part successful, to "bring it all together." This is quite a challenge, given that much of the book is made up of separate, independent field investigations operating across different locations, scales and time periods. From the first four chapters, I had the impression that the book was a mosaic in which the pieces did not quite fit together. Chapter 5 makes the overall picture clearer, linking together history, geopolitics, migration and mobility through the trifocal lenses of memory, space and identity.

Indeed, the time-space variations in the mobilities described in the empirical chapters of the book offer important lessons for the broader study of migration as a complex socio-spatial phenomenon. Migration cannot be considered as a one-shot, unidirectional move from an origin. Few migrations are that simple, and the evidence assembled by Pierre Sintès in his exhaustive research in and around the margins of Greece amply demonstrates that. In these borderlands between Greece, Albania and North Macedonia, multiple cross-border movements have been documented, especially in the wake of the collapse of the communist regime in Albania and the break-up of Yugoslavia. Meanwhile, on the island of Rhodes, complex histories of the Jewish community are unfolded - not only of the effects of the Holocaust, but of migration, deportation, exile, diaspora and "roots return." Throughout the book's analysis, the empirical material presented illustrates well the tension between the increased and multi-directional rhythms of mobility produced by globalisation, and a recurring discourse on locality, roots, identity and return.

What more could have been written? Within a book of this length, not much; however, the lack of attention to the decade of the 2010s in a publication of 2019 is somewhat regrettable. Personally, I missed a more detailed theoretical discussion of ethnicity and, perhaps more fundamentally, any explicit attention paid to gender, the Balkans being one of the most patriarchal regions of Europe. Surely gender dynamics affected the 
author's research; a name-check on research participants turns up Mihail, Giorgio, Christos, "Mr. V" etc., with hardly any women informants. Secondly, the focus on the 2008 economic crisis, which is posed at the beginning as a key pivot for the book, becomes progressively lost and blurred as the narrative proceeds. And finally a couple of technical glitches: the shadings on some of the figures are not so clear (the result of rendering coloured designs into black and white); and not all of the terms asterisked in the text as glossary items are actually in the glossary.

INDEX

Geographical index: Grèce

\section{AUTHORS}

RUSSELL KING

University of Sussex

r.king[at]sussex.ac.uk 